\title{
PEMANFAATAN BENGKUANG (Pachyrhizus Erosus) AFKIR UNTUK PEMBUATAN BEDAK DINGIN PADA KELOMPOK WANITA TANI BERKAT YAKIN KEC. BATANG ANAI KAB. PADANG PARIAMAN
}

\author{
Alfi Asben*, Deivy Andhika Permata, Ira Desri Rahmi, dan Risa Meutia Fiana \\ Jurusan Teknologi Hasil Pertanian, \\ Fakultas Teknologi Pertanian, \\ Universitas Andalas, Limau Manis, 25163, Padang \\ *E-mail: alfi_asben@yahoo.com
}

\begin{abstract}
ABSTRAK
Pengabdian kepada masyarakat ini bertujuan untuk mengurangi kerugian petani dan pedagang bengkoang serta mengoptimalkan umbi bengkoang kelompok tani dengan peningkatan nilai tambah melalui produk bedak dingin. Umbi bengkoang yang tidak terjual lagi dan diangkap afkir dimana kurang layak untuk jadi produk olahan pangan dimanfaatkan untuk membuat bedak dingin. Pengabdian masyarakat ini dilakukan dengan tahapan : 1) Pembuatan dan pengujian bedak dingin bengkoang dengan menggunakan 3 (tiga) jenis ketuaan umbi bengkoang. Pengamatan yang dilakukan meliputi rendemen, derajat warna putih, $\mathrm{pH}$ dan uji organoleptik bedak dan uji iritasi ; dan 2) Penyuluhan dan demontrasi/pelatihan pembuatan bedak dingin pada kelompok mitra. Pada penyuluhan disampaikan: i) Potensi umbi bengkoang, ii) Faktor-foktor yang perlu diperhatikan dalam penentuan bengkoang afkir, dan iii) Faktor yang diperhatikan dalam membuat produk bermutu baik dan dapat disimpan dalam jangka waktu yang lama. Hasil dari kegiatan pengabdian ini adalah : 1) Bengkoang afkir (sisa yang tidak terjual) mempunyai potensi dan dapat serta aman untuk dijadikan bedak dingin; 2). Hasil penelitian (pengujian) bedak dingin bengkoang afkir memberikan hasil yang hampir sama dengan bedak dingin menggunakan bengkoang segar ataupun bengkoang yang panen tua (5-5.5 bulan). Pati bengkoang afkir lebih tinggi dari bengkoang segar dan kadar air yang lebih rendah; dan 3). Anggota kelompok wanita tani Berkat Yakin dapat memahami dan mampu membuat bedak dingin bengkoang afkir yang baik untuk dapat disimpan dalam waktu yang lama.
\end{abstract}

Kata kunci: Bengkoang afkir, Bedak dingin, Pengabdian, Kelompok wanita tani

\section{UTILIZATION OF REJECT BENGKOANG (Pachyrhizus Erosus) ON COLD MASK PRODUCTION IN BERKAT YAKIN FARMER WOMEN GROUP AT SUB DISTRICT OF BATANG ANAI DISTRICT OF PADANG PARIAMAN}

\section{Alfi Asben*, Deivy Andhika Permata, Ira Desri Rahmi, dan Risa Meutia Fiana}

\author{
Department of Agricultural Product Technology, \\ Faculty of Agricultural Technology, \\ Andalas University, Limau Manis, 25163, Padang \\ *E-mail: alfi_asben@yahoo.com
}

\begin{abstract}
The aim of the community service were to reduce losses of bengkoang farmers and traders, and also to optimize bengkoang tubers farmer groups with increased value added through cold mask products. Bengkoang tubers that not sell anymore and considered reject where less feasible to be food products used to make the cold mask. This community service was done by stages: 1) Making and testing of cold mask bengkoang by using 3 (three) maturity types of bengkoang tuber. The observations included rendement, white color, $p H$, organoleptic test of mask, and irritation test; and 2) Counseling and demonstration / training of making cold mask in group of partner. In the counseling delivered: i) Bengkoang tuber potency, ii) Factors to consider in determining reject bengkoang, and 3) Factors considered
\end{abstract}


in making good quality products and can be stored for long periods. The results of this community service activity were: 1) Reject bengkoang (unsold remnant) has the potential and can and safe to be used as cold mask; 2). The cold mask product of reject bengkoang had same quality with cold mask using fresh bengkoang or old harvested bengkoang (5-5.5 month). Starch of reject bengkoang higher than fresh bengkoang and it's water content is lower; and 3). Members of farmer women group Berkat Yakin can understand and able to make cold mask from reject bengkoang and good to be stored for a long time.

Keywords: Reject bengkoang, Cold mask, Community service, Farmer women group

\section{PENDAHULUAN}

Bengkoang (Pachyrhizus erosus) yang merupakan tanaman famili leguminosae pada umumnya memberikan hasil dalam bentuk umbian. Umbi bengkoang merupakan bahan pangan yang dapat langsung dikonsumsi ataupun diolah menjadi bentuk lain. Bengkoang mengandung vitamin $\mathrm{C}$, vitamin B1, protein, dan serat kasar relatif yang tinggi. Bengkoang merupakan diet rendah kalori, 39 kkal/100g karena mengandung inulin [1].

Selain kandungan nutrisi di atas, bengkoang diketahui juga mengandung bahan antioksidan. Menurut [2], umbi bengkoang mengandung antioksidan, termasuk didalamnya vitamin $\mathrm{C}$, flavonoid dan saponin yang mampu mencegah kerusakan kulit oleh radikal bebas. Umbi bengkoang juga mengandung senyawa fenolik yang dapat menghambat pembentukan melanin (pigmentasi) akibat sinar ultra violet (UV) matahari dan mampu menghilangkan bekas jerawat dan pengaruh negatif kosmetik. Berdasarkan keberadaan antioksidan dan bahan flavonid dan fenolik dalam bengkuang, maka bengkoang dapat diproses menjadi produk lainnya baik pangan fungsional, produk farmasi dan kosmetika. Salah satu produk yang dapat dipromosikan dari umbi bengkoang adalah bedak dingin bengkoang untuk kecantikan.

Salah satu daerah penghasil bengkoang (Pachyrrhizus erosus) untuk wilayah propinsi Sumatera Barat adalah Kecamatan Batang Anai Kabupaten Padang Pariaman. Kelompok wanita tani (KWT) Berkat Yakin adalah satu kelompok tani yang aktif membudidayakan dan menghasikan bengkoang (Pachyrrhizus erosus) yang berada di Korong Olo Bangau Kanagarian Ketaping, Kecamatan Batang Anai, Kabupaten Padang Pariaman. Daerah ini berbatasan langsung dengan Kota Padang (bagian selatan). Seperti umum diketahui bahwa bengkoang merupakan komoditi yang menjadi ikon kota Padang ini. Menurut [2], bengkong kota Padang dan sekitarnya disebut-sebut jauh lebih unggul dari bengkoang daerah lain. Lebih lanjut dijelaskan, bengkoang kota Padang adalah varietas unggul dimana rasanya enak dan tahan cukup lama dalam keadaan segar serta beraroma khas.

Lebih lanjut [3] menyatakan secara umum diketahui bahwa umur simpan 
bengkoang segar sangat pendek hanya berkisar 3-4 hari, setelah itu bengkoang tidak dapat dilakukan konsumsi segar lagi. Penyimpanan yang pendek ini menyebabkan petani tidak bisa mengoptimalkan manfaat bengkoang, apalagi penyimpangan telah melewati waktu yang cukup lama sehingga diversifikasi untuk pangan olahan tidak baik lagi. Hal ini memerlukan alternatif bentuk pengolahan dalm bentuk produk lain.

Kelompok wanita tani Berkat Yakin yang beranggota kurang lebih 26 orang dan saat ini diketua oleh Ibu Yulianis (40 thn), sebagian anggota dalam usaha bengkoang baru sebatas menghasilkan umbi tanaman bengkoang untuk langsung dijual ke pasar (konsumen). Dari pengabdian masyarakat sebelumnya yaitu tahun 2015 telah dikenalkan juga variasi produk dari olahan bengkoang. Pada pengabadian masyarakat yang telah dilaksanakan tersebut telah membuka wawasan kelompok tani untuk meningkatkan penjualan bengkoang lewat diversivikasi produk olahan pangan bengkoang, dimana sebagian anggota telah memproduksi olahan bengkuang tersebut untuk pangan seperti pembuatan cake bengkoang walaupun belum berjalan baik dari segi komersial.

Potensi dari umbi bengkoang lain adalah dapat dilakukannya variasi produk bukan hanya untuk produk olahan pangan. Umbi bengkoang sangat potensial dijadikan produk kecantikan dalam bentuk bedak dingin. Bedak dingin biasanya diproduksi dari umbi bengkoang yang sudah tua (umur panen 5-5.5 bulan). Lewat pengabdian masyarakat ini di sosialisasikan dan coba diproduksi bedak dingin bengkoang yang berasal dari umbi bengkoang afkir yang tidak dapat dijual lagi dalam bentuk segarnya karena telah mengalami penurunan kualitas untuk konsusmi segar. Diversifikasi umbi bengkoang afkir ini diharapkan dapat mempertahankan dan juga meningkatkan pendapatan petani bengkoang dalam kelompok tani mitra.

Biasanya untuk konsumsi langsung bengkoang (gajah) pada umur 3-4 bulan dipanen, apabila umurnya lebih tua maka kandungan seratnya menjadi tinggi dan pati yang terbentuk jadi lebih banyak serta umbi jadi lebih keras sehingga tidak sesuai lagi untuk dikonsumsi langsung. Bengkoang petani yang cukup tua dan terlambat panen dapat dimanfaatkan lebih lanjut dimana bisa diolah terutama diambil patinya sebagai bahan kosmetik yaitu bedak dingin

Diversifikasi produk biasanya menyebabkan terjadi perubahan bentuk dari bahan baku menjadi produk $1 / 2$ jadi ataupun produk jadi. Produk diversifikasi bengkoang dapat meningkatkan umur simpan yang akan memberikan nilai tambah lebih tinggi bagi pekerja dikomoditi ini. Peningkatan nilai tambah akan meningkatkan pendapatan dari petani atau pekerja dikomoditi bengkoang ini. Nilai tambah agroindustri dapat dinyatakan sebagai suatu nilai yang tercipta akibat kegiatan mengubah input pertanian 
menjadi produk atau yang dihasilkan dari kegiatan mengolah hasil pertanian menjadi produk akhir [4]. Bentuk diversifikasi produk bengkoang ini tergantung dari kandungan dan kondisi fisiologis bengkoang itu sendiri. Berdasarkan hasil pengabdian masyarakat tahun 2015 pada Kelompok Wanita Tani Berkat Yakin, [5] melaporkan terlihat adanya keinginan dan potensi untuk melakukan pengembangan usaha bengkoang dengan melakukan proses pengolahan umbi menjadi bedak dingin bengkoang. Hal ini terutama dalam mengoptimalkan umbi bengkoang, dimana bengkoang yang tidak terjual (afkir) ini jika digunakan untuk produk pangan bengkoang olahan dirasakan kurang baik. Dengan diversifikasi produk bedak dingin ini hasil budidaya bengkoang kelompok mitra tetap memberikan hasil yang optimal. Keadaan ini lebih lanjut akan mendorong peningkatan pendapatan mereka. Pelatihan dan bimbingan untuk transfer pengetahuan dalam melakukan pengolahan bengkoang terutama dalam memproduksi bedak dingin bengkoang untuk kecantikan telah dilakukan dalam kegiatan ini. Anggota KWT berkat yakin telah memahami cara pengolahan bendak dingin bengkoang yang agak berbeda dalam prosedurnya jika menggunakan bengkoang tua atau segar. Pelatihan ini akan dapat mendorong dalam peningkatan pendapatan anggota KWT yang menanam bengkoang. Anggota KWT berkat yakin mempunyai keinginan kuat dalam memanfaatkan dan mendiversifikasi komoditi bengkoang afkirnya jadi bedak dingin.

\section{Tujuan Kegiatan}

Kegiatan pengabdian ini bertujuan untuk : 1) Mengetahui karakteristik bedak dingin bengkoang afkir, 2) Memperkenalkan / transfer pengetahuan proses pengolahan bengkoang afkir menjadi bedak dingin3) Membimbing mitra untuk dapat dan mampu melakukan proses pembuatan bedak dingin bengkoang afkir yang baik dan tahan lama.

\section{METODOLOGI KEGIATAN}

\section{Waktu dan Tempat}

Kegiatan Pengabdian Masyarakat ini dilakukan pada KWT Berkat Yakin sebagai mitra, yang berlokasi di Korong Olo Bangau Nagari Ketaping, Kecamatan Batang Anai Kabupaten Padang Pariaman. Kegiatan dilaksanakan selama kurang lebih 3 bulan (diawali dengan penelitian pembuatan bedak dingin bengkoang afkir selama 2 bulan).

\section{Metode Pelaksanaan}

Kegiatan Pengabdian yang akan dilakukan dibagi atas tahap-tahap sebagai berikut:

1. Pengujian dan produksi bedak dingin bengkoang di laboratorium dengan menggunakan 3 jenis bahan baku yaitu :

(A) Bengkoang konsumsi; (B)

Bengkoang afkir; dan (C)

Bengkoang lewat panen (usia 5-5.5 bulan)

Bedak dingin bengkoang diproduksi dengan menggunakan wewangian 
aroma Rose. Proses penelitian

dilakukan dengan 3 kali ulangan.

Adapun proses secara umum

pembuatan bedak dingin mengikuti

metode [2] Rukmana dan

Yudirahman (2014). Dari pembuatan

bedak dingin akan diamati :

Rendemen; derajat warna putih, $\mathrm{pH}$

[6] dan uji organoleptic [7].

2. Penyampaian dan introduksi teknologi pembuatan bedak dingin bengkuang afkir. Kegiatan diikuti demontrasi dan pelatihan pengolahan bengkoang menjadi produk bedak dingin. Kelompok wanita tani Berkat Yakin diperkenalkan cara pengolahan bengkoang afkir menjadi produk bedak dingin dengan memperhatikan faktor pemilihan bengkoang afkir yang layak dimana akan mempengaruhi mutu dan lama penyimpanan bedak dingin bengkoang.

Penyampaian informasi (introduksi teknologi), demontrasi dan pelatihan pembuatan produk dilakukan dilokasi tempat Kelompok Wanita Tani Berkat Yakin berada.

\section{HASIL DAN PEMBAHASAN}

\section{Hasil Pengujian dan Produksi Bedak Dingin Bengkoang}

Hasil penelitian/pengujian awal dan produksi bedak dingin bengkoang yang dibuat dari bengkoang afkir dibandingkan dengan bengkoang segar dan bengkoang tua , dapat dilihat pada Tabel 1 dan 2.

Tabel 1. Hasil Pengujian Terhadap Beberapa Keadaan Bengkoang dan Patinya.

\begin{tabular}{lcccl}
\hline \multicolumn{1}{c}{ Bahan } & \multicolumn{3}{c}{ Pengamtan } \\
\cline { 2 - 5 } & Kadar Air (\%) & Pati (\%) & Rendemen (\%) & \multicolumn{1}{c}{ Kondisi Umbi } \\
\hline Bengkoang & & & & \\
- Segar & $85-90$ & 7.91 & 2.098 & Segar, warna putih \\
- Afkir & $70-80$ & $7.10-14.48$ & 2.291 & Keriput, berjamur, coklat tua \\
& & & & Agak keras, liat, coklat muda \\
- Tua & $80-85$ & - & 1.96 & \\
\hline
\end{tabular}

Cat : Kadar air (KA) pati bengkoang 10\% ; (-) tidak dianalisis

Tabel 2. Pengamatan Karakteristik dan Kesukaan Terhadap Bedak Dingin Bengkoang

\begin{tabular}{clccc}
\hline No. & \multicolumn{1}{c}{ Parameter Uji } & \multicolumn{3}{c}{ Kandungan /Penilaian } \\
\cline { 3 - 5 } & & Bengkoang Segar & Bengkoang Afkir & Bengkoang Tua \\
\hline 1 & $\mathrm{pH}$ & 5.7 & 5.3 & 5.5 \\
2 & Derajat putih (L*) & 92.66 & 92.36 & 92.87 \\
3 & Jumlah mikroba (ALT) & $5.2 \times 10^{3}$ & $1.4 \times 10^{4}$ & $9.5 \times 10^{3}$ \\
& $* *$ & & &
\end{tabular}


4 Iritasi (setelah

pemakainan)

(terasa dingin,

(terasa dingin,

(terasa dingin, segar) segar) segar)

$5 \quad$ Uji Organoleptik ***

4.47

3.93

3.67

Cat : * Pengujian menggunakan Hunter Lab (colorimetric), semakin tinggi nilai L makin putih

** Pati bengkoang tidak disterilisasi (oven)

*** Rata-rata dari aroma, warna, tekstur ( 5 =sangat suka, $4=$ suka, $3=$ biasa)

Pada Tabel 1. dan 2. dapat diketahui

bahwa karakteristik bedak dingin bengkoang

afkir tidak jauh berbeda dari bedak dingin

bengkoang segar dan bengkoang tuan. Secara

keseluruhan terlihat bahwa $\mathrm{pH}$, derajat putih dan kesukaan konsumen untuk bendak dingin bengkoang afkir lebih rendah dari bedak dingin bengkoang segar dan bengkoang tua, tapi dalam batasan yang dapat diterima (suka). Dari uji iritasi tidak memberikan pengaruh terhadap perubahan kesehatan kulit, dan terasa dingin dan menyegarkan.

Pada pengamatan rendemen , kandungan pati dan kadar air pada umbi, nilai bengkoang afkir lebih baik. Dimana untuk kadar pati dan rendemen pati bengkoang afkir lebih tinggi dari yang lain. Hal ini menyatakan pada berat yang sama produk bedak dingin benkoang yang didapatkan kan lebih banyak. Hal ini disebabkan kadar air bengkoang afkir yang lebih rendah.

Pada penilaian kandungan mikroba, bedak dingin bengkoang afkir lebih tinggi dari bedak dingin asal bengkoang segar dan bengkoang tua. Jumlah ini belum mempengaruhi kesehatan kulit pemakainya, hal ini diketahui dari uji iritasi yang negatif.
Jumlah ALT yang terdapat pada bedak dingin ini masih di bawah batas yang ditetapkan untuk bahan sediaan perawatan kulit (masker, lulur, mangir dan peeling) yaitu sebesar $10^{5}$ [8]. Terdapatnya sejumlah mikroba pada bedak dingin karena proses pengolahan tidak menggunakan tepung pati bengkoang yang disterilisasi. Jika dilakukan sterilisasi (dioven) jumlah mikroba sangat berkurang dan cenderung minimum. Mikroba berpengaruh dalam penyimpanan bedak dingin dalam jangka waktu tertentu. Jika terdapat sejumlah mikroba pada produk sedangkan KA produk cukup tinggi, maka produk akan cepat mengalami kerusakan. Pada bedak dingin akan dapat ditumbuhi jamur yang diperlihatkan warna bedak yang hijau atau mencoklat. Kondisi yang sama dapat dijumpai pada penyimpanan tepung pati bengkoang yang mempunyai KA diatas $10 \%$ dengan adanya sejumlah mikroba tertentu. Oleh sebab itu dalam pembuatan bedak dingin bengkoang perlu pengeringan sampai KA kecil dari 10\%.

Berikut disajikan gambar bentuk bedak dingin yang dihasilkan dari 3 jenis bengkoang 

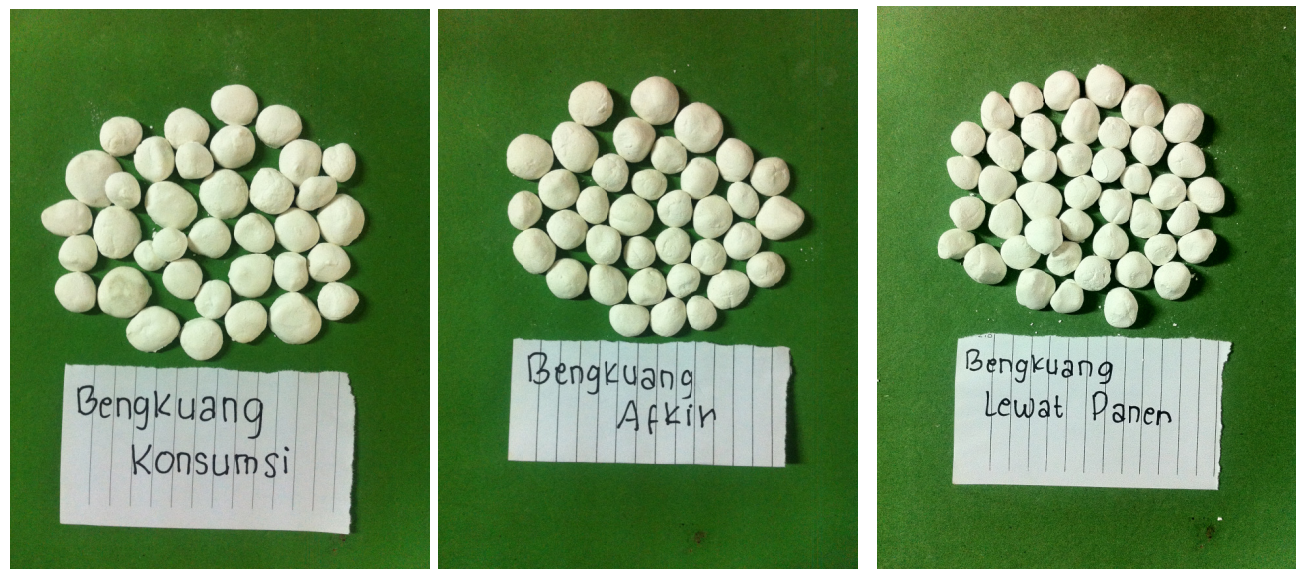

Gambar 1. Produk bedak dingin dari 3 kondisi bengkoang

Penyuluhan dan Demontrasi / Pelatihan

Pembuatan Bedak Dingin Bengkoang

Afkir Pada kelompok Wanita Tani Berkat Yakin

Kegiatan penyuluhan dan demontrasi pelatihan pembuatan produk bengkoang serta cara pengemasan dilakukan pada hari Rabu tanggal 23 November 2016. Tim pengabdian hadir dengan jumlah 10 orang, yaitu 5 orang dosen dan 5 orang mahasiswa/i. Anggota KWT Berkat Yakin yang hadir hampir 90\% yaitu sekitar 26 orang. Pada pertemuan ini dihadiri juga oleh Ibu Syamsiwarnis, SP sebagai PPL Ketaping Kec dan 2 orang rekan PPL Batang Anai. KWT Berkat yakin ini aktif melakukan aktifitas dan kegiatan dibawah PPL ibu Syamsiwarnis, SP.

Dalam penyampaian dan sambutan dari PPL pendamping dan Ketua Kelompok disampaikan bahwa KWT ini aktif melakukan pertemuan setiap minggu pada hari rabu. Kegiatan KWT dibidang pengolahan tanaman pertanian termasuk dalam kegiatan pembibitan. Bibit yang dihasilkan dijual kelompok untuk sebagian disimpan sebagai kas kelompok. Di wilayah Ketaping- termasuk wilayah KWT Berkat Yakin- ada kurang lebih $20 \mathrm{Ha}$ pertanaman bengkoang, dimana luas tanam bengkoang kelompok ada 2 Ha. Permasalahan yang sering ditemui menurut anggota KWT sering ditemui jika bengkoang sudah tidak terjual dalam 7 hari mutunya sudah turun untuk dikomsumsi segar, dan minat konsumen untuk membeli sudah turun sehingga cederung nilai jualnya sudah sangat berkurang. Selama ini alternative yang dilakukan untuk mengatasi ini adalah dengan pengolahan jadi bedak tapi tidak mempunyai mutu bagus dan mudah rusak. Pelatihan ini merupakan solusi yang dibutuhkan KWT.

$$
\text { Pertemuan dalam kegiatan }
$$
pengabdian ini dilakukan 2 sesi, yaitu: 1) penyampaian materi penyuluhan dan diskusi; dan 2) demontrasi dan pelatihan pembuatan bedak dingin bengkoang afkir. Pada pertemuan juga diserahkan alat penghancur umbi bengkoang menjadi bentuk yang lebih 
halus sebelum diekstrak patinya, yaitu berupa blender dari tim pengabdian masyarakat kepada ketua kelompok KWT.

(i) Penyuluhan dan Introduksi Proses Produksi Bedak Dingin Bengkoang Afkhir

Penyuluhan dan demontrasi produk olahan telah dapat dilakukan dengan baik. Penyuluhan dilakukan dengan penyampaian informasi tentang : 1) potensi bengkoang afkir menjadi bedak dingin; 2) faktor yang perlu diperhatikan dalam pemilihan bengkoang afkir yang akan digunakan; dan 3) faktor yang perlu diperhatikan sehingga bedak dingin bisa disimpan lama. Penjelasan disampaikan oleh ketua tim pengabdian masyarakat. Setelah penyuluhan dan penjelasan pengolahan bedang dingin bengkoang afkir dilanjutkan dengan demontrasi pembuatan produk bedak dingin bengkoang. Demontrasi pembuatan produk bengkoang dilakukan oleh mahasiswa/i yang diikuti oleh anggota kelompok.

Dalam penjelasan awal perihal potensi bengkoang afkir jadi bedak, dijelaskan bahwa, bengkoang afkir adalah bengkoang yang tidak dapat terjual untuk konsumsi segar dan kurang layak untuk produk olahan pangan bengkoang. Bengkoang afkir dapat dibagi atas : (1) Bengkoang yang setelah dipanen memang memberikan tampilan yang tidak baik, berulat dan berkerut; dan (2) bengkoang yang telah melewati masa segarnya karena tidak dapat terjual untuk konsumsi pangan.
Bengkoang afkir dapat berupa tampilan ; (1) Basah berlendir karena adanya jamur dan bakteri (mikroba) yang telah tumbuh dan merusak umbi bengkoang, dan (2) Kering, kisut dan mengkerut, karena kadar airnya telah berkurang, dimana umbi terkena udara kering selama penjualan atau penyimpanan. Kebanyakan umbi bengkoang afkir yang ditemukan pada pedagang terlihat umbinya mengkerut (mengering) dan berwarna kecoklatan. Kondisi bengkoang yang mulai mengering ini menyebabkan kandungan patinya menjadi lebih tinggi jika dibandingkan dari bentuk segarnya.

Umbi yang ditumbuhi jamur atau bakteri tidak terlalu banyak ditemui karena pedagang cenderung memotong tipis permukaan bagian umbi yang tidak ada kulitnya sehingga mikroba tidak terlihat tumbuh. Jika permukaan umbi yang tidak berkulit dibiarkan maka akan ditumbuhi mikroba. Keadaan ini mengambarkan dimana kondisi segar bengkoang telah hilang sehingga tidak menarik untuk konsumsi segar dan untuk olahan pangan. Umumnya kadar air bengkoang ini turun sehingga kandungan patinya jadi meningkat (tinggi) (Tabel 1).

Produktivitas bengkoang di kecamatan Batang Anai cukup tinggi dimana iklim dan kondisi pertanaman untuk bengkoang sangat mendukung, dan juga wilayah ini berbatasan dengan kota Padang yang dikenal sebagai kota bengkoang. Bengkoang kota Padang dikenal sebagai 
bengkoang dengan variates yang termasuk unggul di Indonesia.

Pemilihan bengkoang afkir jadi bahan baku bedak dingin haruslah memperhatikan tingkat kerusakan bengkoang, dimana ditandai dengan semakin banyaknya ditemui mikroba (jamur atau cendawan) diumbi yang afkir. Jika terlalu rusak tidak dipakai, dan yang kerusakanya/pertumbuhan jamurnya masih ditolerir akan dipakai dengan membuang bagian yang rusak. Berikutnya perlu diketahui kadar air awalnya dimana akan menentukan jumlah pati yang akan didapat. Pada umumnya dijumpai bengkoang afkir mengandung air relatif lebih rendah sehingga pati menjadi lebih banyak.

Dalam menjaga mutu dan lama waktu penyimpanan bedak dingin bengkoang afkir, dalam pengolahan dilakukan 2 kali pencucian dan terakhir sterilisasi tepung bengkoang dengan menggunakan oven pada suhu $100{ }^{\circ} \mathrm{C}$ selama 30 menit. Hal ini sesuai urutan proses pengolahannya, yaitu sortasi umbi bengkoang afkir, pembuangan bagian yang rusak, pencucian I, pengupasan, pencucian II, pemarutan, pembuburan, pemerasan, pengendapan pati, pemanenan pati, pengeringan (10\%), penepungan, dan pengayakan. Langkah terakhir adalah sterilisasi (pengovenan) tepung bengkoang.

Pada penyampaian teknologi pengolahan bedak dingin bengkoang afkir diperlihatkan contoh bengkoang afkir dan produk bedak bengkoang afkir, seperti Gambar 2. dan 3 berikut ini.
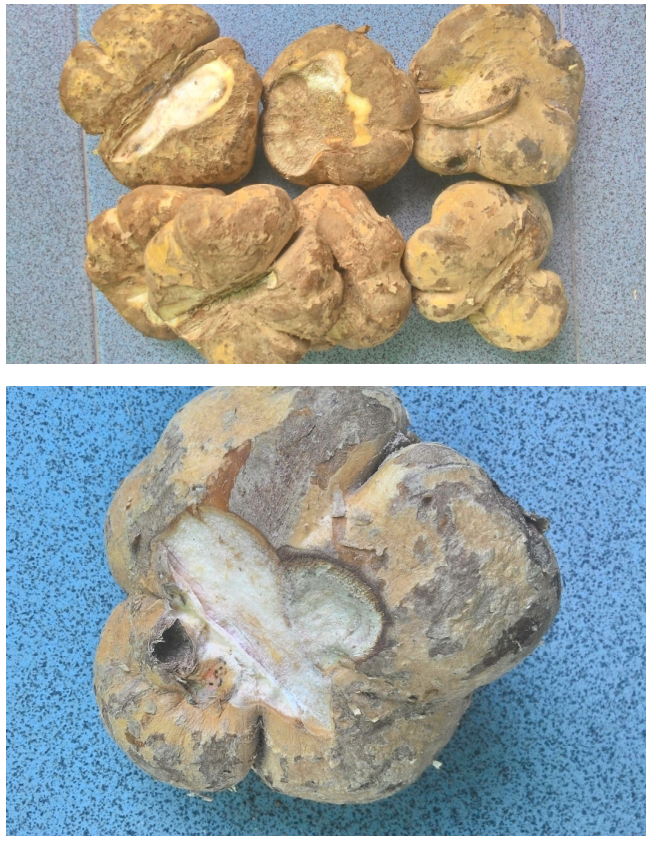

Gambar 2. Contoh bengkoang afkir yang digunakan untuk pembuatan bedak dingin dalam pelatihan

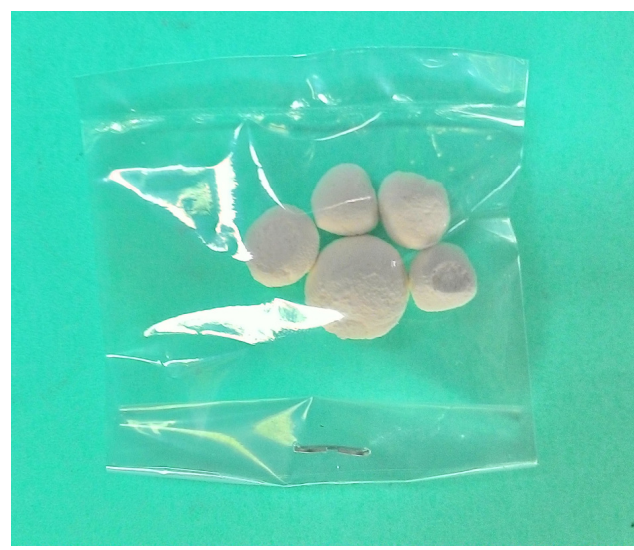

Gambar 3. Produk bedak dingin bengkoang afkir

(ii) Demontrasi dan Pelatihan Pembuatan Bedak Dingin Bengkoang Afkir

Demontrasi dilakukan oleh mahasiswa/i, dan diikuti oleh ibu-ibu anggota kelompok dengan antusias. Seluruh bahan baku dan bahan penunjang serta alat pengolahan disediakan oleh tim pengabdian masyarakat. Demontrasi dan pelatihan 
disampai secara bertahap dimana setiap bengkoang memerlukan waktu untuk tahapan proses tim pengabdian telah mencapai KA $10 \%$, dan pencetakan serta menyediakan bentuk produk antara olahan pengeringan bedak ding bengkoang perlu jadinya. Bahan produk antara yang waktu untuk sampai jadi bedak dingin yang disediakan meliputi 1) penyediaan telah kering (KA kecil 10\%). Penyediaan bengkoang afkir yang akan diolah, 2) produk antara dan produk akhir bedak dingin penyediaan pati bengkoang hasil ekstraksi bengkoang memudahkan anggota kelompok yang sudah dikeringkan, dan 3) penyedian produk bedak dingin bengkoang afkir yang telah jadi. Penyediaan produk antara dan produk akhir ini membantu dalam pelatihan karena jika diikuti prosedur secara berurutan akan sangat lama. Proses ekstraksi perlu untuk memahami dan menguasai proses pembuatan bedak dingin ini dengan baik.

Adapun tahapan proses demontrasi dan pelatihan pembuatan bedak dingin bengkoang afkir ini dapat dilihat pada Gambar 4. berikut ini.

waktu untuk pengendapan, pengeringan pati

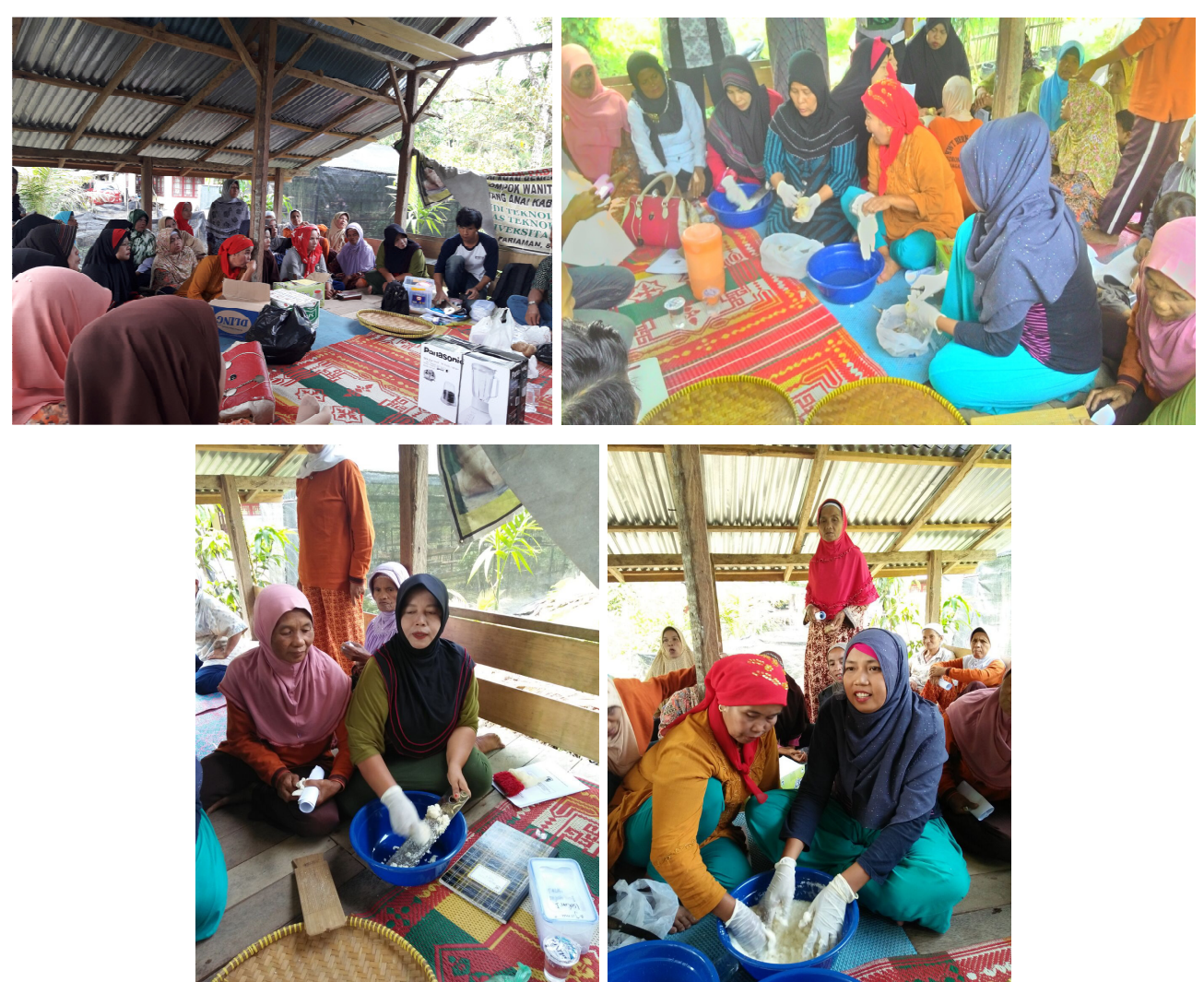

Gambar 4. Proses demontrasi dan pelatihan pembuatan bedak dingin bengkoang afkir pada KWT Berkat yakin

Berdasarkan evaluasi kegiatan yang dilakukan, pemahaman dan kemampuan anggota KWT Berkat Yakin dalam menghasilkan produk bedak dingin dari bengkoang afkir sudah sangat baik. Hal ini akan semakin meningkatkan nilai tambah 
dari komoditi bengkoang yang mereka hasilkan, sehingga semakin minim yang terbuang.

\section{KESIMPULAN}

1. Bengkoang afkir (sisa yang tidak terjual) mempunyai potensi dan dapat serta aman untuk dijadikan bedak dingin.

2. Hasil penelitian (pengujian) bedak dingin bengkoang afkir memberikan hasil yang hampir sama dengan bedak dingin menggunakan bengkoang segar ataupun bengkoang yang panen tua (5-5.5 bulan). Pati bengkoang afkir lebih tinggi dari bengkoang segar dengan kadar air yang lebih rendah.

3. Anggoat KWT Berkat Yakin dapat memahami dan telah mampu membuat bedak dingin bengkoang afkir yang baik untuk dapat disimpan dalam waktu yang lama.

\section{UCAPAN TERIMA KASIH}

Ucapan terima kasih disampaikan kepada Direktorat Jenderal Penguatan dan Pengembangan, Kementerian Riset, Teknologi dan Pendididikan Tinggi lewat Universitas Andalas yang telah membantu pembiayaan Kegiatan Pengabdian Masyarakat ini melalui skim PPM Kompotitif Prodi 2016.

\section{DAFTAR PUSTAKA}

[1] Noman, A.S.M., Hoque, M.A., Haque, M.M., Pervin, F., Karima, M. R. 2007. Nutritional and anti-nutritional components in Pachyrhizus erosus
L. tuber. J. Food Chemistry 102: issue 4

[2] Rukmana, R dan H. Yudirachman. 2014. Kiat Sukses Budi Daya Bengkuang: Tanaman Multi Manfaat. Lily Publisher. Yogyakarta.

[3] Agusdiayanto. 2011. Pati Bengkuang untuk Produk Kecantikan.

http://tapiokapati.wordpress.com/20 $\underline{11 / 03 / 12 / \text { pati-bengkuang-untuk- }}$ produkkecantikan/.

November 2015).

[4] Sa'id EG, Intan AH. 2000. Menghitung Nilai Tambah Produk Agribisnis. Komoditas 11(19): 48.

[5] Asben, A., D.P. Permata., P.D. Hari dan R.M. Fiana, 2015. Pelatihan Pengolahan Bengkoang (Pachyrhizus erosus) Pada Kelompok Wanita Tani Berkat Yakin Kec. Batang Anai Kab. Padang Pariaman. (Laporan Pengabdian Kepada Masyarakat). Fak. Teknologi Pertanian. Univ. Andalas. Padang

[6] AOAC. 1995. Official Methods of Analysis. The Association of Official Analytical Chemistry. AOAC Int. Washintong DC.

[7] Setyaningsih, D., Apriyantono,A dan D.K Sari. 2010. Analisis Sensori untuk Industri Pangan dan Agro. IPB. Bogor.

[8] Direktur Jenderal Pengawasan Obat dan Makanan. 1994. Keputusan Direktur Jenderal Pengawasan Obat dan Makanan HK.00.06.4.02894 tanggal 23 November 1994; Persyaratan Cemaran Mikroba Pada Kosmetika. Dirjen Pengawasan Obat Dan Makanan. Depertemen Kesehatan RI. Jakarta. 